\title{
ZOOHYGIENIC CHARACTERISTICS OF BIOTECHNOLOGICAL METHODS OF METABOLISM REGULATING OF CHICKENS EMBRYO IN THE PROCESS OF INCUBATION
}

\author{
Bordunova Olga Georgievna \\ Doctor of Agricultural Sciences, Proffesor \\ Sumy National Agrarian University \\ ORCID: 0000-0002-7120-1040 \\ E-mail: bordunova.olga59@gmail.com
}

Samokhina Evgeniya Anatoliyivna

$\mathrm{PhD}$, Associate Professor

Sumy National Agrarian University

ORCID: 0000-0002-0983-3047

E-mail: evgeniya_samokhina@ukr.net

Khmelnychyi Leontiy Mykhailovych

Doctor of Agricultural Sciences, Professor

Sumy National Agrarian University

ORCID: 0000-0001-5175-1291

E-mail: khmelnychy@ukr.net

Povod Mykola Grigorovich

Doctor of Agricultural Sciences, Proffesor

Sumy National Agrarian University ORCID 0000-0001-9272-9672

E-mail: snau.cz@ukr.net

Vechorka Victoria Viktorivna

Doctor of Agricultural Sciences, Professor

Sumy National Agrarian University

ORCID: 0000-0003-4956-2074

E-mail: vvvechorka@gmail.com

The research presents the results of experimental studies of the influence of various physicochemical factors (phonophoresis, electrophoresis, electrospray, diffusion, etc.) on the rate of transport of biologically active substances through the protective layer of hatching eggs shell of crossbred Haysex Brown. The aim of the study was to compare the effectiveness of the use of physicochemical methods of transportation of biologically active substances through the shell of hatching eggs of chickens. For the experiment, three batches of eggs were formed, which were obtained from layer hens Haysex Brown, 144 pieces in each experimental group. The kinetic parameters of BAS transport through bioceramic protective barriers of eggs were calculated based on the determination of BAS concentration on the surface and inside the egg by mass spectrometric method (mass spectrometer with ionization of ${ }^{252} \mathrm{Cf}$ fission fragments "MSBH", (Ltd "SELMI", Sumy, Ukraine). The degree of permeability of bioceramic layers of the shell relative to the model gas mixture which is identical to the atmospheric air was studied by the method of $\mathrm{V}$. Breslavets et other and the mass spectrometric method (gas mass spectrometer "MX 7304A"). Electron microscopic studies were performed on a scanning electron microscope REMMA-102; Visilog 6.11 (Noesis, Belgium) was used to process the obtained digital images to determine the number of shell microdefects per unit area of the digital image. It has been experimentally proved that to increase the efficiency of transport of biologically active substances (BAS) through the bioceramic layers of the shell of hatching eggs of Loman Brown hens, it is advisable to use ultrasonic treatment (phonophoresis, sonophoresis), substances - enhancers, including plant terpenes (Lmenthol), DMSO and cyclodextrin. Phonophoretic treatment of hatching eggs increases the hatchability of eggs by $7.6 \%$. At the same time, the gas permeability of the bioceramic layer increases significantly (by $0.43 .10-4 \mathrm{~m}^{3} / \mathrm{m}^{2} \mathrm{~s}$ ).

Key words: biotechnology, technology, egg incubation, disinfectants, biologically active substances.

DOl: https://doi.org/10.32845/bsnau.lvst.2021.1.5

One of the newest promising approaches to the urgent problem of increasing the hatchability of hatching eggs and the quality of young poultry is the regulation of metabolism of avian embryos during incubation using various physicochemical factors, including biologically active substances (BAS) of synthetic and natural origin $[1,3,8,14,17]$. Despite the fact that, as shown by numerous studies, as a BAS can be used a variety of organic and inorganic substances, and still remain unresolved certain aspects of non-destructive transport of these BAS through the bioceramic protective barrier of eggshell $[2,7,10$, 21].

The problem of delivery of BAS to the area embryo development is achieved by fundamentally different methods $[5,6$, $9,25]$. One of them is the introduction of BAS and vaccines in the middle of the hatching egg ("in ovo") using a precision needle microdose (technology Embrex Inc., USA). However, this

Вісник Сумського національного аграрного університету 
technology involves a local violation of the integrity of the bioceramic layer $[4,11]$. Also known are technologies for regulating the metabolism of avian embryos that use passive and active transport of BAS through the bioceramic layer. The main driving factor of the first is the free diffusion of substances that are part of the BAS, through the calcite layer of the shell $[12,15,18,19]$.

Factors of active transport include accelerated diffusion and transfer by means of "transporter molecules" and so-called "enhancers" - substances that enhance the transfer processes $[13,24,26]$. Peculiarities of both approaches to transshell transfer are combined in the technology of "artificial cuticle" for hatching eggs [16]. We note that due to the complex, multicomponent and heterogeneous structure of bioceramic and glycoprotein protective layers of the shell and supra- and subshell membranes, detailed studies of the mechanisms and kinetic parameters of transport of organic substances that are part of BAS, different molecular weight, shape and charge [20, 22, 23, 27].

The aim of the study was a comparative study of the efficiency of transport of biologically active substances through the shell of hatching eggs of Haysex Brown chickens.

Materials and methods of research. The work used hatching eggs (15-20 weeks of egg-laying), obtained from a high sex brown bird, which was kept in accordance with the established norms of keeping and feeding. The kinetic parameters of BAS transport through bioceramic protective barriers of eggs were calculated based on the determination of BAS concentration on the surface and inside the egg by mass spectrometric method (mass spectrometer with ionization by $252 \mathrm{Cf}$ fragments "MSBH", (Ltd "SELMI", Sumy, Ukraine). Reagents: creatine phosphate disodium salt, $5 \%$ (Sigma, USA), adenosine monophosphate (AMP) (Sigma, USA), glutamine (Glu) (Serva, Germany), cysteine (Cis) (Reanal, Hungary), dimethyl sulfoxide (DMSO); -cyclodextrin, (Sigma, USA)*. The composition of the model aqueous solution of BAS (MR-BAS) for experiments to determine the efficiency of transport of BAS in the middle of the egg: $\operatorname{AMP}(0.1 \%)+$ Glu $(0.1 \%)+$ Cis $(0.1 \%)+$ creatine phosphate disodium salt $(0.1 \%)$. Concentrations of substances "enhancers": DMSO (0.05-1.5\%), $\alpha$ - cyclodextrin (0.5-3.0\%), Lmenthol (0.5-2.5\%), quaternary ammonium compounds (QAC) CID-20 (CID-Line, Belgium) (0.5-2.0\%). The study of the efficiency of transporting BAS in the middle of the egg $(n=144)$ was performed as follows:

Control (Intensity of BAS diffusion under conditions of equal temperatures outside and inside the egg): $50 \mu \mathrm{l}$ of MRBAS was applied to the lateral surface of the egg (thermostat; humidity 95-98\%; 18 $\pm 0.20 \mathrm{C} ; 12$ hours);

Group 1 (Free diffusion of BAS under conditions of elevated temperature inside the egg): egg kept in a thermostat for 2 hours at a humidity level of $95-98 \% ; 25 \pm 0,2 \mathrm{C}$, immersed for 15 minutes in a solution of MR-BAS $15 \pm 0,10^{\circ} \mathrm{C}$ (water thermostat);

Group 2 (Substance "enhancer" $\alpha$ - cyclodextrin): $50 \mu \mathrm{l}$ of MR-BAS $+\alpha$ - cyclodextrin $(0.5 \%)$ was applied to the lateral surface of the egg (thermostat; humidity $95-98 \% ; 180 \pm 2{ }^{\circ} \mathrm{C} ; 12$ hours) ;

Group 3 "Substance" enhancer "from the group of terpenes (L-menthol): on the side surface of the egg was applied $50 \mu$ of MR-BAS + L-menthol $(0.5 \%)$ (thermostat; humidity 95 $98 \% ; 180 \pm 2^{\circ} \mathrm{C} ; 12$ hours);

Group 4 (DMSO enhancer substance): on the side sur- face of the egg was applied $50 \mu$ l of MR-BAS + DMSO (0.05\%) (thermostat; humidity $95-98 \% ; 18 \pm 2{ }^{\circ} \mathrm{C} ; 12$ hours);

Group 5 "Substance"enhancer "from the QAC group (CID-20): on the side surface of the egg was applied $50 \mu \mathrm{l}$ of MR-BAS + CID-20 (0.5\%) (thermostat; humidity 95-98\%; $18 \pm 2^{\circ} \mathrm{C} ; 12$ hours);

Group 6 (Hydraulic shock): a solution of MR-BAS was applied to the side surface of the egg with a diameter of $0.3 \mathrm{~mm}$ in a pulsed mode $(0.5 \mathrm{~s})$ under a pressure of $2.5 \mathrm{~atm}$ for 2 minutes:

Group 7 (Electrophoresis): on the side surfaces of the egg from above and below were placed foam washers with a diameter of $1 \mathrm{~mm}$, saturated with a solution of MR-BAS $(1 \mathrm{ml})$. Platinum electrodes were connected to the washers (voltage 3.5 $\mathrm{V}$; current direct; $10 \mathrm{~min}$.; thermostat $180 \pm 2^{\circ} \mathrm{C}$

Group 8 (Electrospray "electrospray") (diameter of droplets of aerosol of solution MR-BAS $200 \mathrm{~nm}-1 \mu \mathrm{m}$; voltage + $7 \mathrm{kV}$;

Group 9 (Phonophoresis; sonophoresis; ultrasonic treatment)]; $180 \pm 0,2^{0}, 22 \mathrm{kHz}$ for 2-15 s).

The degree of permeability of bioceramic layers of the shell relative to the model gas mixture which is identical to the atmospheric air was studied by the method of V. Breslavets et al. [3] and mass spectrometric method (gas mass spectrometer "MX 7304A"). Electron microscopic studies were performed on a scanning electron microscope REMMA-102, when processing the obtained digital images to determine the number of microdefects of the shell per unit area of the digital image $(Y$; number of channels,\%; table), used the program Visilog 6.11 (Noesis, Belgium). Experimental results (repetition not less than $n=5$ ) were processed statistically using the package Statistica 5.1.

Results of research and discussion. The table shows the results of a series of experiments comparing the degree of efficiency of methods of transporting BAS through the biocrystalline layer of the shell. The control was taken as the amount of BAS received by conventional diffusion for 12 hours at a humidity level of $95-98 \%$ and a temperature of $180 \pm 0,2^{\circ} \mathrm{C}$; in the middle of the egg at equal temperatures outside and inside the egg. At the end of the experiment, a drop of BAS on the outer surface of the shell was dried, then the egg was carefully retrieved from the protein and yolk, dried again, then selected $0.5 \mathrm{~cm} 2$ shell with a layer of BAS applied to the outer surface, broken into 2 equal parts, fixed on the disk surface to keep the sample of the device "IASB" (one part of the outer surface, the other inner). Thus, the analysis of the organic component of the outer and inner surfaces of the shell allowed a comparison in a certain approximation of the number of BAS received during incubation in the middle of the egg. Thus, in the case of normal diffusion in the middle of the egg received $0.03 \pm 0.009 \%$ of the amount of BAS contained on the surface.

The table shows that the most promising factors for nondestructive transfer of BAS through the biocrystalline layer are ultrasonic treatment (phonophoresis, sonophoresis), plant terpenes (L-menthol), which are already used in biotechnology as enhancers of BAS transport through natural protective structures (leather, bioceramics, etc.), DMSO and CD.

In particular, phonophoretic treatment of hatching eggs of Lohmann Brown crosses increases the hatchability from the initial value of $80.4 \%$ to $88.0 \%(+7.6)$. This significantly increases the gas permeability (up to 1.91 from the initial value 
of $\left.1.48 .10^{-4} \mathrm{~m} 3 / \mathrm{m} 2 \mathrm{~s}\right)(+0.43)$ under conditions of transfer to the middle of the egg $79.2 \%$ of the BAS of the total number of

eggs applied to the surface (Table 1).

Comparison of the efficiency of different physicochemical methods of transportation

Table 1 of biologically active substances (BAS) in the middle of hatching eggs

(cross Lohmann brown)

\begin{tabular}{|c|l|c|c|c|c|}
\hline $\begin{array}{c}\text { 年 } \\
\text { 응 }\end{array}$ & \multicolumn{1}{|c|}{$\begin{array}{c}\text { Kind of } \\
\text { transportation }\end{array}$} & $\begin{array}{c}\text { The content of BAS } \\
\text { in the middle of the } \\
\text { egg, } \% \text { of control }\end{array}$ & $\mathrm{Y}, \%$ & $\begin{array}{c}\text { Gas permeability } \\
10^{-4} \mathrm{M}^{3} / \mathrm{M}^{2} \mathrm{C}\end{array}$ & $\begin{array}{c}\text { Eggs } \\
\text { hatching, } \\
\%\end{array}$ \\
\hline $\mathrm{C}$ & $\begin{array}{l}\text { Control (intensity of diffusion of BAS under conditions of equal } \\
\text { temperatures outside and in the middle of the egg). }\end{array}$ & $0,03 \pm 0,009$ & $65,2 \pm 1,84$ & $1,48 \pm 0,052$ & $80,4 \pm 2,42$ \\
\hline 1 & $\begin{array}{l}\text { Free diffusion of BAS under conditions of elevated temperature in } \\
\text { the middle of the egg }\end{array}$ & $2,5 \pm 0,11^{* *}$ & $65,0 \pm 2,33$ & $1,48 \pm 0,091$ & $81,1 \pm 3,10$ \\
\hline 2 & Cyclodextrins (CD) & $13,4 \pm 0,09^{* *}$ & $65,6 \pm 0,71$ & $1,56 \pm 0,173^{*}$ & $85,6 \pm 0,71^{*}$ \\
\hline 3 & L-menthol & $58,2 \pm 0,27^{* *}$ & $65,0 \pm 1,54$ & $1,49 \pm 0,562$ & $86,0 \pm 0,94^{*}$ \\
\hline 4 & Dimethyl sulfoxide (DMSO) & $65,1 \pm 0,14^{* *}$ & $66,0 \pm 2,03$ & $1,48 \pm 0,183$ & $86,0 \pm 0,22^{*}$ \\
\hline 5 & Quaternary ammonium compounds (QAC) CID-20 & $10,8 \pm 0,31^{* *}$ & $65,6 \pm 2,40$ & $1,44 \pm 0,114$ & $82,8 \pm 1,61$ \\
\hline 6 & Hydraulic shock & $22,1 \pm 0,05^{* *}$ & $81,1 \pm 1,33^{* *}$ & $1,51 \pm 0,273$ & $81,7 \pm 0,40$ \\
\hline 7 & Electrophoresis & $56,4 \pm 0,23^{* *}$ & $78,0 \pm 3,44^{* *}$ & $1,71 \pm 0,363^{* *}$ & $86,0 \pm 2,33^{*}$ \\
\hline 8 & Electrospray & $35,3 \pm 0,16^{* *}$ & $69,4 \pm 1,73^{*}$ & $1,56 \pm 0,150^{*}$ & $82,8 \pm 2,03$ \\
\hline 9 & Phonophoresis & $79,2 \pm 0,08^{* *}$ & $74,0 \pm 2,11^{* *}$ & $1,91 \pm 0,091^{* *}$ & $88,0 \pm 1,10^{* *}$ \\
\hline
\end{tabular}

Notes: ${ }^{*} P<0,05 ;{ }^{* *} P<0.01$.

It is noteworthy that there is no unambiguous correlation between the level of morphological "ordering" of bioceramic layers of the shell, which in our work is expressed by $Y$ (the number of microdefects in the shell per unit area of digital image of the shell), and the level of gas permeability of the bioceramic layer. Thus, the number of microdefects of the bioceramic layer per unit area of the shell in comparison with the control significantly increases (+ 15.9\%) under the influence of "hydraulic shock", as well as with the use of phonophoretic techniques $(+$ $8.8 \%$ relative to control). However, the corresponding increase in the number of BAS received in the middle of the egg is + $22.07 \%$ and $79.17 \%$ compared to the control. These results provide grounds for assuming the existence of different mechanisms of transfer of organic compounds through the bioceramic layer in the first and second cases. In particular, phonophoretic technology is based on the use of ultrasonic radiation, which is characterized by the so-called "sonocapillary effect", which consists in multiple (sometimes orders of magnitude) enhancement of capillary transport of liquid phase substances in heterogeneous solid phase media.

At the same time, the technique of "hydraulic shock", which has proven itself well in devices for non-destructive transfer of liquid substances through the membrane systems of living tissues, in the case of solid-phase structures is not effective enough. In this aspect, the electrospray technique proved to be more effective - as can be seen from the table, the number of microdefects of the bioceramic layer per unit area of the shell does not differ significantly from the control. However, the efficiency of trans shell transfer exceeds the corresponding figure inherent in the technique of "hydraulic shock" by $58.1 \%$.

According to our data, very promising are the classic substances- "enhancers" - DMSO and plant terpenes (Lmenthol). These substances significantly increase the rate of trans shell shell transfer ( $+65.07 \%$ and $58.17 \%$, respectively) and at the same time have little effect on the degree of ordering of heterogeneous layers of bioceramics (table). DMSO and Lmenthol also have a positive effect on the egg hatchability, although they are not able to increase the gas permeability of the bioceramic layer.

Conclusions. It has been experimentally proved that to increase the efficiency of transportation of biologically active substances (BAS) through the bioceramic layers of the shell of hatching eggs of Loman Brown chickens, it is advisable to use ultrasonic treatment (phonophoresis, sonophoresis), enhancers, including plant terpenes (L-menthol), DMSO and cyclodextrin.

Phonophoretic treatment of hatching eggs increases the hatchability of eggs by $7.6 \%$. At the same time, the gas permeability of the bioceramic layer increases significantly (by 0.43 . 10-4 m3 / m2 - s).

Acknowledgment. The work has been performed under the financial support of the Ministry of Education and Science of Ukraine (state registration number 0119U100551).

\section{References:}

1. Bessarabov, B. F., 2006. Inkubatsiya yaits s osnovami embriologii selskohozyaystvennoy ptitsyi [Incubation of eggs with the basics of poultry embryology]. M : Kolos, pp. 264.

2. Breslavets, V. O., 2006. Doslidzhennia hazo- ta volohopronyknosti shkaralupy yaiets kurei riznykh porid ta viku [Investigation of gas and moisture permeability of eggshells of chickens of different breeds and ages]. Ptakhivnytstvo : mizhvid. temat. nauk. zb. IP UAAN, issue 58, pp. 355-360.

3. Breslavets, V. O., 2001. Inkubatsiia yaiets silskohospodarskoi ptytsi : metodychnyi posibnyk [Incubation of poultry eggs: a guide]. Kh: IEiKVM., pp. 92.

4. Dobrenko, A., 2010. Obrabotka yaits v magnitnom pole. Ptitsevodstvo. № 4. S. 21 - 22.

5. Ivanov, V. O., 2004 Vplyv biolohichno aktyvnykh rechovyn, vvedenykh khimichnym sposobom v yaytse, na vyvodymist' yayets' m'yasnykh i yayechnykh ptakhiv. Suchasne ptakhivnytstvo. issue 4, pp. 2 - 3. 
6. Kirillov, N. K., 2001. Elektrofizicheskiye metody vozdeystviya v tekhnologii inkubatsii yaits Izv. Nats. Akad. Nauki $i$ iskusstv Chuvashskoy Resp. T.5., № 2, pp. 63 - 68.

7. Medvedev, A., 2001. Bezopasnyie sredstva dlya dezinfektsii. [Safe disinfectants]. Ptitsevodstvo, issue 4, pp. 37-41.

8. Prokudina, N. A., 2008. Inkubatsiya yaits selskohozyaystvennoy ptitsyi [Incubation of poultry eggs].H.: «NTMT», pp. 386.

9. Sakhatskyi, I., 2005. Dezinfektsiini zasoby dlia ptakhivnytstva: porivnialna efektyvnist [Disinfectants for poultry: comparative effectiveness]. Veterynarna medytsyna Ukrainy, issue 1, pp. 40-43.

10. Stehnii, B. T., 2005. Porivnialna otsinka preparative dlia peredinkubatsiinoi obrobky yaiets [Comparative evaluation of drugsforpre-incubation treatment of eggs]. Mizhnarodnyi tematychnyi naukovyi zbirnyk. Kharkiv. T. 2, issue 85, pp. $1022-1025$.

11. lakubchak, O. M., 2006. Chym krashche obrobyty? Porivnialna otsinka suchasnykh I tradytsiinykh dezinfektsiinykh zasobiv, shcho vykorystovuiutsia $v$ haluzi ptakhivnytstva [What is more beautiful to grind? Ratio assessment of the occasional and traditional disinfectious diseases, how to get sick in the branch poultry]. Suchasne ptakhivnytstvo, issue 6. pp. 14-15.

12. Yakymenko, I. L., 2003. Rehulyatorna diya monokhromatychnoho vydymoho svita neteplovoyi intensyvnosti na rozvytok ptytsi (za funktsionuvannyam enerhetychnoyi, hidroksylyuyuchoyi ta antyoksydantnoyi system) : avtoref. dys. ... doktora biol. nauk: 03.00.02; Kyyivs'kyy nats. un-t. - K., p. 34.

13. Wei Xiao, Junbo Xu, Xiaoyan Liu, Qiaoling Hub and Jianguo Huang, 2013. Antibacterial hybrid materials fabricated by nanocoating of microfibril bundles of cellulose substance with titania/chitosan/silver-nanopartic le composite films. J. Mater. Chem. B, issue 1, pp. $3477-3485$.

14. Balaz, M., 2014. Eggshell membrane biomaterial as a platform for applications in materials science. Acta Biomaterialia. V. 10, issue 9, pp. 3827-3843. doi:10.1016/j.actbio.2014.03.020.

15. Bain, M. M., Mc dade, K., Burchmore, R., Law, A., Wilson, P. W., Schmutz, M., Preisinger, R. and Dunn, I. C., 2013. Enhancing the egg's natural defence against bacterial penetration by increasing cuticle deposition. Animal Genetics. V. 44, issue 6, pp. 661-668. doi: 10.1111/age.12071.

16. Bordunova, O. G., Samokhina, Y. A., Loboda, V. B., Chernenko, O. M., Dolbanosova, R. V. and Chivanov, V. D., 2020. Study of the correlations between the dynamics of thermal destruction and the morphological parameters of biogenic calcites by the method of thermoprogrammed desorption mass spectrometry (TPD-MS). Springer Proceedings in Physics, Springer, Singapore, issue 240, pp. 37-50. https://doi.org/10.1007/978-981-15-1742-6

17. D'Alba, L., Jones, D. N., Badawy, H. T., Eliason, C. M. and Shawkey, M. D., 2014. Antimicrobial properties of a nanostructured eggshell from a compost-nesting bird. Journal o Experimental Biology, issue 217 (7), pp. 1116-1121.

18. D’Alba, L., Maia, R., Hauber, M. E. and Shawkey, M. D., 2016 Evolution of avian eggshell structure in relation to nesting ecology. Proc. R. Soc. Lond. B. V. 283: 20160687.doi: 10.1098/rspb.2016.0687.

19. Gole, V. C., Roberts, J. R., Sexton, M. and Kiermeier, A., 2014. Effect of egg washing and correlation between cuticle and egg penetration by various Salmonella strains. International Journal of Food Microbiology, issue. 182-183, pp. 18-25. doi: j.ijfoodmicro.2014.04.030.

20. Gang, Xiao., 2015. Synthesis of core-shell bio a ffinity chitosan- $\mathrm{TiO}_{2}$ composite and its tnvironmental applications. Journal of Hazardous Materials, issue 283, pp. 888-896.

21. Su, Hyun Kim, Hong, Kyoon, No and Witoon, Prinyawiwatkul., 2007. Effect of Molecular weight, type of chitosan, and chitosan solution pH on the shelf-life and quality of coated eggs, Journal of food science. Vol. 72, issue 1, pp. 44-48.

22. Bain, M. M., Mcdade, K. and Burchmore, R., 2013 Enhancing the egg's natural defence against bacterial penetration by increasing cuticle deposition. Animal Genetics.DOI: 10.1111. - age. 12071.

23. Liu, Z., Sun, X., Cai, C., He, W. and Linhardt, R. J., 2016 Characteristics of glycosaminoglycans in chicken eggshells and the influence of disaccharide composition on eggshell properties. Poultry Science. V. 95, issue 12, pp. 2879-2888. doi: 10.3382/ps/pew179.

24. Maria, P., Montero Garcia, M., Carmen, G., M. and Gustavo, V., 2017. Edible films and coatings: fundamentals and applications.CRC Press, Taylor \& Francis Group. Issue 24, pp. 598.

25. Maureen, B., Yves, N. and Filip, V., 2011. Immerseel food science, technology and nutrition improving the safety and quality of eggs and egg products: Volume 2: Egg safety and nutritional quality. Woodhead Publishing. Issue 38, pp. 448.

26. Yuceer, M. and Caner, C., 2014 Antimicrobial lysozyme-chitosan coatings affect unctional properties and shelf life of chicken eggs during storage. J. Sci. Food Agric, issue 94, pp.153-162. doi: 10.1002/jsfa.6322.

27. Yu, Shao, Changsheng, Cao, Shiliang, Chen, Miao, He, Xiaofang, Li and Danzhen, Li., 2015. Investigation of nitrogen doped and carbon species decorated TiO2with enhanced visible light photocatalytic activity by using chitosan. Applied Catalysis B: Environmental, issue 179, pp. 344-351.

\section{Список використаної літератури:}

1. Бессарабов Б. Ф. Инкубация яиц с основами эмбриологии сельскохозяйственной птицы. М: Колос. 2006. С. 264.

2. Бреславець В. О. Дослідження газо- та вологопроникності шкаралупи яєць курей різних порід та віку. Птахівництво : міжвід. темат. наук. зб. ІП УААН. 2006. № 58. С. 355-360.

3. Бреславець В. О. Інкубація яєць сільськогосподарської птиці : методичний посібник. X. : ІЕіКВМ. 2001. С. 92.

4. Добренко А. Обработка яиц в магнитном поле. Птицеводство. 2010. № 4. С. 21-22.

5. Іванов В.О. Вплив біологічно активних речовин, введених хімічним способом в яйце, на виводимість яєць м'ясних і яєчних птахів. Сучасне птахівництво. 2004. № 4. С. 2-3. 
6. К Кириллов Н.К. Электрофизические методы воздействия в технологии инкубации яиц Изв. Нац. Акад. Науки и искусств Чувашской Peсn. 2001. Т.5., № 2. С. 63-68.

7. Медведев А. Безопасные средства для дезинфекции. Птицеводство. 2001. № 4. С. 37-41.

8. Прокудина Н. А. Инкубация яиц сельскохозяйственной птицы. Х.: «НТМТ», 2008. С. 386.

9. Сахацький І. Дезінфекційні засоби для птахівництва: порівняльна ефективність. Ветеринарна медицина України. 2005.№ 1. С. 40-43.

10. Стегній Б. Т. Порівняльна оцінка препаратів для передінкубаційної обробки яєць. Міжнародний тематичний науковий збірник. Харків. 2005. Т. 2. № 85. С. 1022-1025.

11. Якубчак О. М. Чим краще обробити? Порівняльна оцінка сучасних і традиційних дезінфекційних засобів, що використовуються в галузі птахівництва. Сучасне птахівництво. 2006. № 6. С. 14-15.

12. Якименко І.Л. Регуляторна дія монохроматичного видимого світа нетеплової інтенсивності на розвиток птиці (за функціонуванням енергетичної, гідроксилюючої та антиоксидантної систем) : авторефр. дис. ... доктора біол. наук: 03.00.02; Київський нац. ун-т. - К., 2003. - 34 с.

13. Wei Xiao, Junbo Xu ,Xiaoyan Liu,Qiaoling Hub and Jianguo Huang.Antibacterial hybrid materials fabricated by nanocoating of microfibril bundles of cellulose substance with titania/chitosan/silver-nanopartic le composite films.J. Mater. Chem. B, 2013, issue 1, pp. 34773485.

14. Balaz M. Eggshell membrane biomaterial as a platform for applications in materials science. Acta Biomaterialia. 2014. V. 10, issue 9, pp. 3827-3843. doi:10.1016/j.actbio.2014.03.020.

15. Bain M.M., Mc dade K., Burchmore R., Law A.,Wilson P. W., Schmutz M., Preisinger R., Dunn I.C. Enhancing the egg's natural defence against bacterial penetration by increasing cuticle deposition. Animal Genetics. 2013. V 44,issue 6, pp. 661668. doi: 10.1111/age.12071.

16. Bordunova O. G., Samokhina Y. A., Loboda V. B., Chernenko O. M., Dolbanosov R. V., Chivanov V. D. Study of the correlations between the dynamics of thermal destruction and the morphological parameters of biogenic calcites by the method of thermoprogrammed desorption mass spectrometry (TPD-MS). Springer Proceedings in Physics, Springer, Singapore, 2020,issue 240. pp. 37-50. https://doi.org/10.1007/978-981-15-1742-6

17. D'Alba L., Jones D. N., Badawy H. T., Eliason C. M., Shawkey M. D. Antimicrobial properties of a nanostructured eggshell from a compost-nesting bird. Journal of Experimental Biology. 2014. issue217 (7),pp. 1116-1121.

18. D'Alba L., Maia R., Hauber M. E., Shawkey M. D. Evolution of avian eggshell structure in relation to nesting ecology. Proc. R. Soc. Lond. B. 2016. V. 283: 20160687.doi: 10.1098/rspb.2016.0687.

19. Gole V. C., Roberts J. R., Sexton M., May D., Kiermeier A., Chousalkar K. K. Effect of egg washing and correlation between cuticle and egg penetration by various Salmonella strains. International Journal of Food Microbiology. 2014. issue. 182-183, pp. 18-25. doi: j.ijfoodmicro.2014.04.030.

20. Gang Xiao. Synthesis of core-shell bioaffinity chitosan- $\mathrm{TiO}_{2}$ composite and its tnvironmental applications. Journal of Hazardous Materials. 2015.issue 283 ,pp. 888-896.

21. Su Hyun Kim, Hong Kyoon No and Witoon Prinyawiwatkul.Effect of Molecular weight, type of chitosan, and chitosan solution pH on the shelf-life and quality of coated eggs, Journal of food science.2007. Vol. 72, issue 1, pp. 44-48.

22. Bain M. M., Mc dade K., Burchmore R. Enhancing the egg's natural defence against bacterial penetration by increasing cuticle deposition. Animal Genetics. 2013. DOI : 10.1111.-age.12071.

23. Liu Z., Sun X., Cai C., He W., Zhang F., Linhardt R. J. Characteristics of glycosaminoglycans in chicken eggshells and the influence of disaccharide composition on eggshell properties.Poultry Science. 2016. V. 95, issue 12, pp. 2879-2888. doi: 10.3382/ps/pew179.

24. Maria P., Montero Garcia, M. Carmen G., M. Elvira L., Gustavo V. Edible films and coatings: fundamentals and applications. CRC Press, Taylor \& Francis Group. 2017. pp. 598.

25. Maureen B., Yves N., Filip V. Immerseel food science, technology and nutrition improving the safety and quality of eggs and egg products: Volume 2: Egg safety and nutritional quality. Woodhead Publishing. 2011. pp. 448.

26. Yuceer M., Caner C. Antimicrobial lysozyme-chitosan coatings affect unctional properties and shelf life of chicken eggs during storage .J. Sci. Food Agric. 2014. issue94, pp.153-162. doi: 10.1002/jsfa.6322.

27. Yu Shao, Changsheng Cao, Shiliang Chen, Miao He, Jialin Fang, Jing Chen, Xiaofang Li, Danzhen Li. Investigation of nitrogen doped and carbon species decorated TiO2with enhanced visible light photocatalytic activity by using chitosan. Applied Catalysis B: Environmental.2015. issue 179, pp. 344-351.

Бордунова Ольга Георгіївна, доктор сільськогосподарських наук, профессор

Самохіна Євгенія Анатоліївна , кандидат сільськогосподарських наук, доцент

Хмельничий Леонтій Михайлович, доктор сільськогосподарських наук, професор

Повод Микола Григорович, доктор сільськогосподарських наук, професор

Вечорка Вікторія Вікторівна, доктор сільськогосподарських наук, профресор

Сумський національний аграрний університет (Суми, Україна)

Зоогігієнічна характеристика біотехнологічних методів щодо регулювання обміну речовин ембріона курей в процесі інкубації

В роботі наведені результати експериментальних досліджень щодо впливу різних фрізико-хімічних чинників (фронофрорез, електрофорез, електророзпилення, дифрузія,тощо) на швидкість транспортування біологічно активних речо- 
вин через захисний шар шкаралупи інкубаційних яєць птиці кросу Хайсекс браун. Метою дослідження було порівняння ефективності використання фрізико-хімічних методів транспортування біологічно активних речовин через шкаралупу інкубаційних яєць курей. Для проведення досліду було сформовано три партії яєць, котрі були отримані від курей-несучок Хайсекс браун, по 144 штук в кожній експериментальній групі. Кінетичні параметри транспортування БАР через біокерамічні захисні бар'єри яєць вираховували виходячи з визначення концентрації БАР на поверхні $і$ всередині яйця масспектрометричним методом (мас-спектрометр з іонізацією уламками поділу 252Cf "MCБX", (ВАT "SELMI", Суми, Україна). Ступінь проникності біокерамічних шарів шкаралупи щодо модельної газової суміші яка є ідентичною атмосферному повітрю, вивчали методом В. О. Бреславця та ін. та мас-спектрометричним методом (газовий мас-спектрометр "МХ 7304A". Електронно-мікроскопічні дослідження проводили на скануючому електронному мікроскопі PEMMA-102; при обробиі отриманих цифрових зображень для визначення кількісті мікродефектів шкаралупи на одиницю площі цифрового зображення, використовували програму Visilog 6.11 (Noesis, Бельгія). Експериментально доведено, що для підвищення есрективності транспортування біологічно активних речовин (БАР) через біокерамічні шари шкаралупи інкубаційних яєць курей кросу Ломан браун доцільно використовувати ультразвукову обробку (фонофрорез, сонофорез), речовини "енхансерu", зокрема рослинні терпени (L-ментол), ДМСО і ЦД. Фонофоретична обробка інкубаційних яєць підвищує показник виводимості яєць на 7,6\%. При цьому значно зростає газопроникність біокерамічного шару (на 0,43 . $\left.10^{-4} \mathrm{M}^{3} / \mathrm{M}^{2} \cdot \mathrm{c}\right)$.

Ключові слова: біотехнологія, технологія, інкубація яєць, дезінфектанти, біологічно активні речовини

Дата надходження до редакції: 26.01.2021 p. 